\title{
SISTEM E-LEARNING BERBASIS MODEL MOTIVASI KOMUNITAS
}

Oleh: Romi Satria Wahono*

\section{Abstract}

e-Learning system is a required solution in education at this globalization era. The existence of e-Learning with information tecnology support bring the transformation from conventional education process into digital form, both content and system perspective. However, recently e-Learning industry is experiencing of crisis, causing to failure and lack of e-Learning implementation in various sector in the world. Failure is especially caused by limited number of user and the lack of motivation to finish eLearning. This paper give solution by developing e-Learning system based on community motivation model which able to overcome the problems regarding to user motivation in the implementation of e-Learning system. Model is developed based on the theory of learning motivation and requirement capturing from the requirement engineering's field. The indicators used to measure the model effectiveness are hit and visit statistics, traffic ranking, comparison with other similar e-Learning system, and the relation between concepts in model. Community motivation model have been implemented in web based public e-Learning systems (IImuKomputer.Com), with the significant results appeared.

Keywords: e-Learning system, community motivation model, requirement engineering

*) Penulis adalah peneliti pada Pusat Dokumentasi Informasi Ilmiah (PDII), Lembaga IImu Pengetahuan Indonesia (LIPI). 


\section{PENDAHULUAN}

Seiring dengan kebutuhan akan metode dan konsep pembelajaran yang lebih efektif dan efisien, pemanfaatan teknologi informasi untuk pendidikan menjadi tidak terelakkan lagi. Konsep yang kemudian terkenal dengan sebutan e-Learning ini membawa pengaruh terjadinya proses transformasi pendidikan konvensional ke dalam bentuk digital, baik secara isi (contents) maupun sistemnya. Darin E. Hartley [Hartley, 2001] mengatakan bahwa e-Learning adalah suatu jenis belajar mengajar yang memungkinkan tersampaikannya bahan ajar ke siswa dengan menggunakan media Internet, Intranet atau media jaringan komputer lain. Saat ini konsep e-Learning sudah banyak diterima oleh masyarakat dunia, terbukti dengan maraknya implementasi e-Learning di lembaga pendidikan (sekolah, training dan universitas) maupun industri (Cisco Systems, IBM, HP, Oracle, dsb).

John Chambers yang merupakan CEO dari perusahaan Cisco Systems mengatakan bahwa aplikasi dalam dunia pendidikan termasuk eLearning didalamnya akan menjadi "killer application" yang sangat berpengaruh di era-era ke depan. Departemen perdagangan dan departemen pendidikan Amerika Serikat bahkan bersama-sama mencanangkan Visi 2020 berhubungan dengan konsep pendidikan berbasis teknologi informasi (eLearning) [U.S. Department of Commerce, 2002]. Konsep e-Learning semakin berkembang karena memiliki banyak keuntungan dibandingkan sistem konvensional [Hannay \& Newvine, 2006].

Di balik hal tersebut, dewasa ini industri e-Learning sedang mengalami krisis, yang berakibat ke kegagalan penerapan e-Learning. Dari sebuah studi tahun 2000 yang dilakukan oleh Forrester Group kepada 40 perusahaan besar menunjukkan bahwa sebagian besar pekerja (lebih dari $68 \%$ ) menolak untuk mengikuti pelatihan atau kursus yang menggunakan konsep e-Learning. Ketika e-Learning itu diwajibkan kepada mereka, 30\% menolak untuk mengikutinya [Dublin \& Cross, 2003]. Sedangkan studi lain mengindikasikan bahwa dari orang-orang yang mendaftar untuk mengikuti eLearning, 50-80\% tidak pernah menyelesaikannya sampai akhir [Delio, 2000]. Bahasa mudahnya, e- 
Learning adalah sesuatu yang secara teori sangat menarik, tetapi ternyata masyarakat tidak terlalu termotivasi untuk memanfaatkannya.

Dari latar belakang kegagalan penerapan e-Learning diatas, penelitian ini memiliki tujuan untuk mencari solusi serta mengembangkan suatu model yang diharapkan dapat digunakan secara tepat dalam penerapan sistem eLearning.

\section{METODOLOGI PENELITIAN}

Pengukuran sistem e-Learning pada hakekatnya menggunakan metodologi umum pengukuran kualitas perangkat lunak. Kajian tentang kualitas perangkat lunak (software quality) adalah tema kajian dan penelitian turun temurun dalam sejarah ilmu rekayasa perangkat lunak (software engineering). Kajian dimulai dari apa yang akan diukur (apakah proses atau produk), apakah memang perangkat lunak bisa diukur, sudut pandang pengukur dan bagaimana menentukan parameter pengukuran kualitas perangkat lunak.

Kualitas perangkat lunak dapat dilihat dari sudut pandang proses pengembangan perangkat lunak (process) dan hasil produk yang dihasilkan (product) (Tabel 1). Dan penilaian ini tentu berorientasi akhir ke bagaimana suatu perangkat lunak dapat dikembangkan sesuai dengan yang diharapkan oleh pengguna. Hal ini berangkat dari pengertian kualitas (quality) menurut IEEE Standard Glossary of Software Engineering Technology [IEEE Std 610.12., 1990] yang dikatakan sebagai: suatu tingkatan dimana sistem, komponen dan proses dapat memenuhi secara tepat kebutuhan atau harapan dari pelanggan (klien).

Dari sudut pandang produk, pengukuran kualitas perangkat lunak dapat menggunakan standard dari ISO 9126 atau best practice yang dikembangkan para praktisi dan pengembang perangkat lunak. Taksonomi McCall adalah contoh best practice untuk pengukuran produk yang cukup terkenal dan diterima banyak pihak [Vliet, 2000]. 
Di lain pihak, dari sudut pandang proses, standard ISO 9001 dapat digunakan untuk mengukur kualitas perangkat lunak. Dan diskusi tentang ini berkembang dengan munculnya tema kajian tentang CMM (The Capability Maturity Model) yang dikembangkan di Software Engineering Institute, Carnegie Mellon University serta beberapa kajian lain seperti SPICE (Software Process Improvement and Capability dEtermination) dan BOOTSTRAP. CMM, SPICE dan BOOTSTRAP mengukur kualitas perangkat lunak dari seberapa matang proses pengembangannya.

Tabel 1: Kualitas Perangkat Lunak dari segi Proses dan Produk

\begin{tabular}{|l|l|l|}
\hline Sudut Pandang & Pengukuran Standard & Pengukuran Non-Standard \\
\hline Product & ISO 9126 & Best Practice \\
\hline Process & ISO 9001 & CMM, SPICE, BOOTSTRAP \\
\hline
\end{tabular}

Dalam penelitian ini sudut pandang yang digunakan untuk pengukuran dan evaluasi sistem adalah dari sudut pandang produk (product). Sedangkan metodologi penelitian yang digunakan adalah sebagai berikut:

1. Pembuatan model berdasarkan teori psikologi pembelajaran [Morgan, 1961] [Martens et al., 2004], business motivation model [Hall et al., 2005] dan teori requirement engineering [Leffingwell \& Widrig, 2000] [Wahono, 2003]

2. Penerapan model untuk pengembangan dan penerapan sistem eLearning IlmuKomputer.Com

3. Analisa hasil dan pengukuran efektifitas model motivasi komunitas menggunakan indikator: statistik kunjungan, traffic ranking, komparasi dengan sistem e-Learning sejenis, dan hubungan antar Konsep dalam model. Data statistik kunjungan diperoleh dengan menggunakan software AWStats (http://awstats.sourceforge.net), Webalizer (http://www.mrunix.net/webalizer), dan juga sistem perangkingan situs web (Alexa.Com). Sedangkan untuk menganalisa hubungan antar Konsep dalam model motivasi komunitas, data diambil dari forum diskusi (mailing list) 
IImuKomputer.Com, serta berbagai majalah, koran, TV yang pernah memuat berita atau laporan tentang IImuKomputer.Com.

\section{MODEL MOTIVASI KOMUNITAS \\ - Pengertian dan Konsep}

Model motivasi komunitas (community motivation model) menyediakan skema atau struktur strategi untuk mengembangkan, mengelola dan berkolaborasi dalam suatu komunitas, sehingga kegiatan atau sistem yang dikembangkan dapat diikuti dengan baik oleh anggota komunitas. Pemikiran tentang model motivasi komunitas sebagian diadopsi dari teori psikologi pembelajaran [Morgan, 1961] [Martens et al., 2004], business motivation model [Hall et al., 2005] dan teori requirement engineering terutama bagaimana mengcapture kebutuhan user (user needs) berhubungan dengan sistem yang dikembangkan [Leffingwell \& Widrig, 2000] [Wahono, 2003].

Dalam bidang ilmu rekayasa perangkat lunak (software engineering), para peneliti membuat model atau pattern yang dapat digunakan kembali (reuse) berdasarkan best practice yang telah terbukti (proven) atau diterima secara umum [Gamma et al., 1995] [Wahono \& Cheng, 2002]. Demikian juga dengan model motivasi komunitas ini, disamping pendekatan teori yang digunakan, model juga semakin matang karena best practice dari pengembangan dan penerapannya di sistem e-Learning IImuKomputer.Com [Wahono, 2004] [Wahono, 2005].

- Diagram Model Motivasi Komunitas

Diagram model motivasi komunitas yang diusulkan adalah seperti pada Gambar 1. Sesuai dengan konsep yang telah dijelaskan diatas, model motivasi komunitas adalah sebuah pattern dan guideline untuk mengembangkan, mengelola dan berkolaborasi dalam suatu komunitas, sehingga kegiatan atau sistem dalam hal ini e-Learning yang akan dikembangkan dapat diikuti dengan baik oleh seluruh anggota komunitas. 
Model terdiri dari 8 Konsep yang masing-masing memiliki Subkonsep dengan sistem hirarki. Konsep adalah unsur utama pembentuk model, sedangkan Subkonsep adalah unsur di bawah Konsep dengan suatu Kategori yang ditetapkan. Hubungan bisa menunjuk ke Konsep maupun langsung ke Subkonsep. Penjelasan lengkap model motivasi komunitas akan dilakukan pada bagian penerapan sistem eLearning, yang mengambil kasus pada pengembangan IlmuKomputer.Com

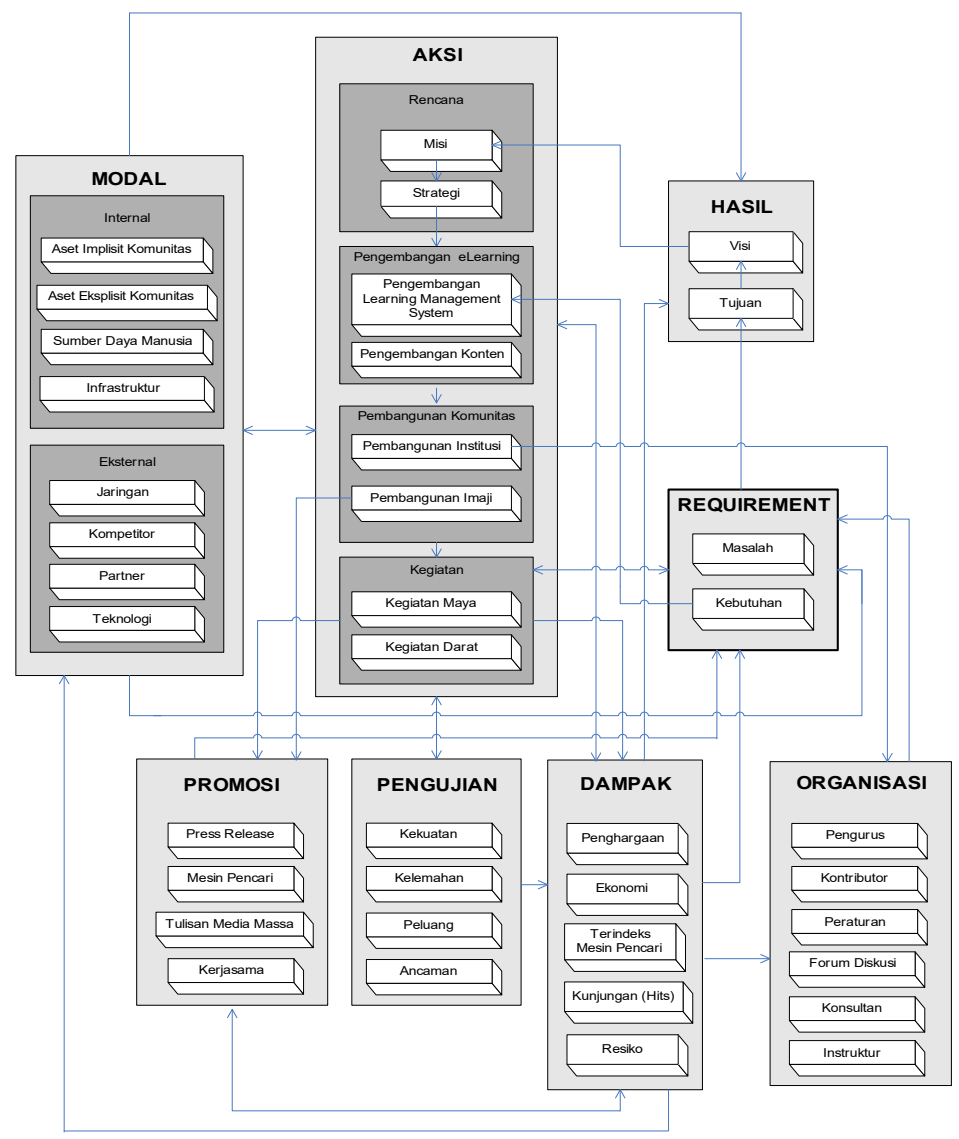

Gambar 1: Diagram Model Motivasi Komunitas 


\section{- Penerapan Sistem e-Learning berbasis Model Motivasi Komunitas}

Bagaimana menghubungkan model motivasi komunitas diatas dengan penerapan e-Learning untuk suatu komunitas, akan diberikan studi kasus bagaimana model tersebut diterapkan di sistem e-Learning IImuKomputer.Com.

1. Pada awal tahun 2003 , dilakukan survey dan diskusi mendalam selama tiga bulan di hampir seluruh mailing list teknologi informasi di Indonesia, terutama yang menggunakan yahoogroups.com sebagai server mailing list. Jumlah total mailing list yang disurvey mencapai 300 mailing list dengan total message perharinya mencapai 900. Hasilnya adalah adanya kebutuhan akan literatur (artikel, tutorial, buku) bertema teknologi informasi yang komprehensif, berbahasa Indonesia, gratis, berformat siap print (PDF) dan tidak terpencar di berbagai tempat. Masalah dan kebutuhan ini tidak terpecahkan karena sistem e-Learning (repositori) dengan materi berbahasa Indonesia yang ada terbatas (benpinter.net, detikinet.com), dan kalaupun ada menggunakan bahasa Inggris (MIT opencourse, eBooks) atau harus membayar. Proses ini dalam ilmu rekayasa perangkat lunak sering disebut dengan requirement capturing atau dalam model motivasi komunitas disebut dengan Konsep REQUIREMENT.

2. Berlatarbelakang masalah dan kebutuhan itu dibuatlah suatu Tujuan dan Visi untuk menyediakan materi teknologi informasi berbahasa Indonesia yang dapat didownload secara gratis oleh siapapun, yang kemudian diberi nama IImuKomputer.Com (Gambar 2). Dan tentu saja diharapkan bahwa sistem ini dikunjungi dan dimanfaatkan oleh banyak pengguna terutama di Indonesia. Jadi hal itulah yang dimasukkan dalam Konsep HASIL. 


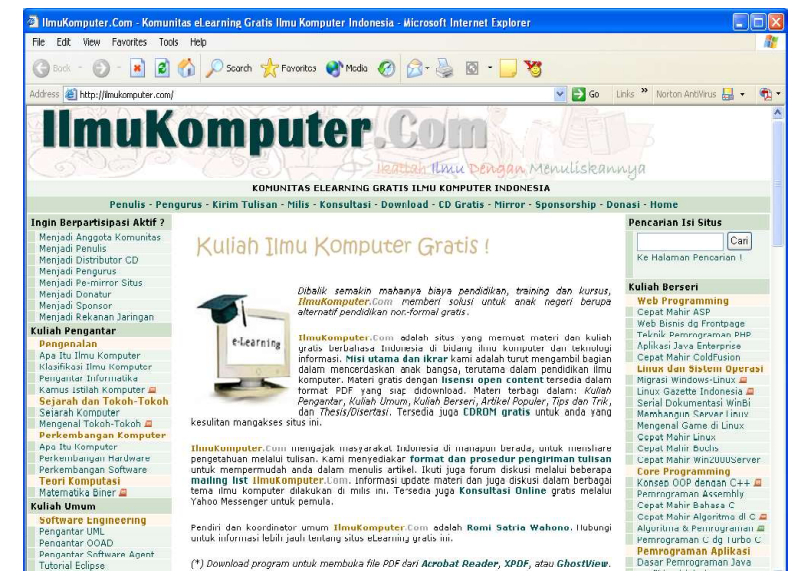

Gambar 2: IlmuKomputer.Com

3. Tujuan dan Visi itu dikongkretkan di Misi dan Strategi pada Konsep AKSI. Realisasinya adalah berupa pegembangan sistem e-Learning baik perangkat lunaknya (Learning Management System (LMS)) maupun konten (content)nya. LMS harus dikembangkan sesuai dengan kebutuhan pengguna yang telah tertangkap pada proses requirement capturing di awal proses. Strategi awal untuk konten adalah dengan menampilkan tulisan-tulisan pengantar yang ringan dan menarik, sambil mengajak beberapa rekan untuk berkontribusi dalam tulisan. Tulisan disajikan dalam format PDF yang siap didownload dan diprint, serta dibagi dalam beberapa kategori, diantaranya adalah Kuliah Pengantar, Kuliah Umum, Kuliah Berseri, Tips dan Trik, dsb. Dimulai dari sekitar 15 artikel pada saat launching, saat ini terkumpul lebih dari 1200 tulisan dalam berbagai kategori di IlmuKomputer.Com.

4. Berikutnya adalah yang penting dari Konsep AKSI ini yaitu pembangunan komunitas (community building). Pembangunan komunitas adalah salah satu tahapan yang sangat menentukan dalam penerapan e-Learning maupun sistem berbasis web 
apapun di dunia [Jo Kim, 2000]. Pembangunan komunitas ini terbagi menjadi dua Subkonsep:

- Pembangunan Institusi (Institution Building): Konsep ini berlandaskan ke bagaimana komunitas membangun diri dari dalam (internal). IlmuKomputer.Com sebagai sebuah komunitas e-Learning menata organisasi, menyusun pengurus, membangun forum diskusi (mailing list), membuat peraturan, dan pengelolaan sumber daya manusia termasuk didalamnya kontributor, konsultan dan instruktur. Hal ini dimodelkan dalam Konsep ORGANISASI.

- Pembangunan Imaji (Image Building): Inti dari Konsep ini adalah bagaimana sistem e-Learning yang dikembangkan bisa tampil di publik. Melakukan press releasing kegiatan komunitas, mendaftarkan sistem e-Learning ke mesin pencari (google.com, yahoo.com, dsb), menulis di media massa cetak maupun elektronik, dan membangun kerjasama dengan pihak lain (negeri maupun swasta). IImuKomputer.Com saat ini telah tampil di berbagai media massa, termasuk koran, majalah dan TV. Hal ini dimodelkan dalam Konsep PROMOSI.

5. Pembangunan komunitas diikuti dengan dilakukannya berbagai kegiatan, baik kegiatan maya (online) maupun darat (offline). Kegiatan darat misalnya dengan workshop, seminar dan training yang sifatnya murah atau gratis. Kegiatan maya dengan seminar online, radio internet, dsb.

6. Konsep AKSI juga memiliki hubungan timbal balik dengan Konsep MODAL yang terdiri dari Modal Internal dan Eksternal. Modal Internal bisa berupa sumber daya manusia yang semakin banyak dan berkualitas, infrastruktur semakin baik. Konsep MODAL semakin memperkuat AKSI, dan AKSI akan semakin menambah MODAL komunitas. Dengan kuatnya MODAL juga semakin meningkatkan REQUIREMENT untuk bergerak lebih jauh, dan memungkinkan terjadi revisi dan perbaikan di Tujuan dan Visi dalam Konsep HASIL. 
7. Konsep AKSI, MODAL dan PROMOSI berhubungan erat dengan Konsep DAMPAK, dimana misalnya IImuKomputer.Com mendapatkan berbagai penghargaan sebagai sistem e-Learning terbaik baik dalam tingkat Internasional (WSIS 2003 di Jenewa) maupun Nasional (Majalah Komputeraktif). Selain itu juga juga dampak ekonomi bagi pengurus, penulis, kontributor dan anggota komunitas IImuKomputer.Com. Dampak positif lain adalah jumlah kunjungan (hits) yang tinggi, dimana ini berimplikasi ke rangking sistem IlmuKomputer.Com di mesin pencari yang semakin tinggi. Menurut [Onggo, 2005] berpromosi yang paling efektif dan efisien saat ini adalah melalui mesin pencari, dan bukan banner iklan atau semacamnya.

8. PENGUJIAN diperlukan untuk mengetahui dimana kekuatan dan kelemahan sistem e-Learning yang dibangun, juga menganalisa peluang serta ancaman yang ada (teori SWOT). Hasil Pengujian dapat dikembalikan ke AKSI, baik dalam perspektif perencanaan, pembangunan komunitas maupun kegiatan (baik offline maupun online). Peluang-peluang yang memungkinkan segera digarap sehingga menimbulkan DAMPAK yang positif, baik berupa kunjungan ke sistem e-Learning yang tinggi (hits), penghargaan (award) maupun dampak ekonomi, misalnya membuka lapangan kerja baru, outsourcing project software, tampil di media, dsb.

\section{HASIL DAN PEMBAHASAN}

Seperti sudah dijelaskan di bagian sebelumnya, sistem e-Learning berbasis model motivasi komunitas telah diterapkan dalam sistem eLearning publik IImuKomputer.Com. Hasil penerapan, data dan analisa lengkapnya akan disampaikan dalam bagian ini. Kemudian untuk melihat sejauh mana efektifitas model yang dikembangkan, juga akan dicoba melakukan komparasi dengan data statistik sistem e-Learning lain yang sejenis, yaitu yang memiliki beberapa karakteristik di bawah: 1. Dikembangkan pada waktu yang hampir bersamaan di awal sampai pertengahan tahun 2003, sehingga memiliki data statistik awal yang kurang lebih sama. 
2. Layanan yang diberikan adalah sama, yaitu materi teknologi informasi secara umum (tidak khusus misalnya hanya linux, microsoft, dsb), berbahasa Indonesia dan gratis di download (berlisensi open content).

3. Tidak menggunakan software tambahan atau agent untuk merekayasa tingkat kunjungan

Dipilihlah sistem e-Learning bernama Sony-ak.Com (Gambar 3), karena memiliki karakteristik diatas.

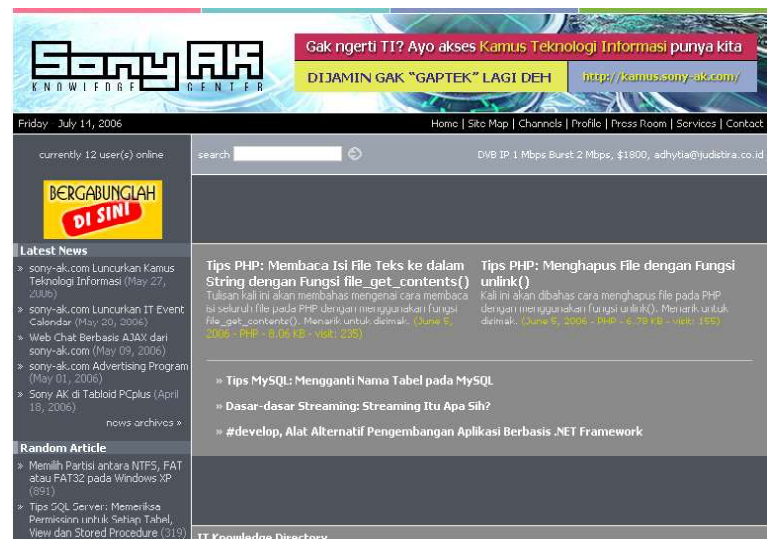

Gambar 3: Sistem e-Learning Sony-ak.Com

Berbeda dengan model motivasi komunitas (Gambar 1), Sony-ak.Com menggunakan strategi pengembangan sistem e-Learning lebih sederhana seperti pada Gambar 4. Tidak mengawali kegiatan dengan metode requirement capturing dalam strategi yang digunakan. Materi disediakan dengan tujuan berbagi pengetahuan dan dokumentasi pribadi. Setelah tujuan terbentuk, dilakukan pengembangan learning management system (LMS) dan konten. Alamat domain didaftarkan di mesin pencari, kemudian menunggu adanya kunjungan yang datang. Pengembangan LMS diikuti dengan pengembangan konten, dan pengupdate-an konten inilah yang menjaga kunjungan (hits) tetap ada. Sonyak. Com tidak mememiliki forum diskusi, tidak melakukan pembangunan komunitas (imaji maupun institusi), tidak melakukan 
kegiatan offline dan online selain berbagi materi, tidak melakukan press releasing, dan tidak pernah menulis di media massa berhubungan dengan sistem e-Learning Sony-ak.Com. Secara keorganisasian (pengurus) juga tidak ada, dan boleh dikatakan hanya dikelola oleh 12 orang.

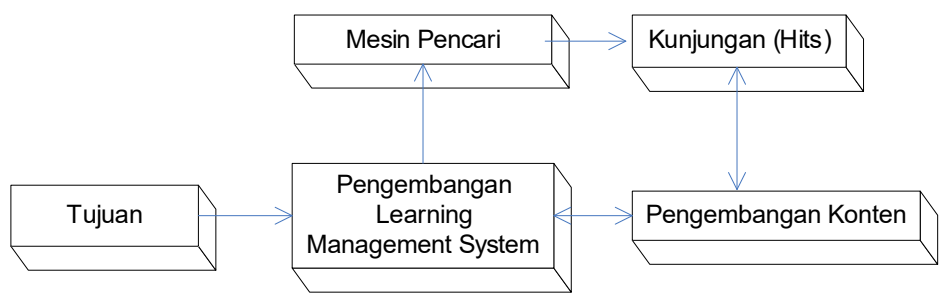

Gambar 4: Strategi Penerapan Sistem e-Learning ala Sony-ak.Com

\section{- Data Statistik Kunjungan}

Hasil statistik umum kunjungan IImuKomputer.Com dan Sonyak.Com dari Januari sampai Juni 2006 beserta komparasinya ditampilkan pada Gambar 5. Sebagai keterangan terminologi yang digunakan adalah sebagai berikut:

1. Month

2. Number of Visits

3. Daily Average's Hits

4. Total Hits

5. Bandwidth
: Bulan dimana data dihitung

: Jumlah kunjungan berdasarkan alamat IP unik

: Jumlah kunjungan rata-rata per hari : Jumlah total kunjungan dalam satu bulan

: Jumlah total ukuran data yang mengalir

(upstream dan downstream) dalam satu bulan

Dari data pada Gambar 5 dapat dilihat bahwa secara umum dari berbagai sudut pandang parameter (Jumlah Kunjungan IP Unik (Number of Visits), Rata-Rata Kunjungan Harian (Daily Average's Hits), Total Kunjungan (Total Hits), Pemakaian Bandwidth), 
IlmuKomputer.Com jauh mengungguli Sony-ak.Com. Perbedaan data statistik kunjungan ini cukup signifikan karena hampir semua parameter berbeda digit dalam nilainya.
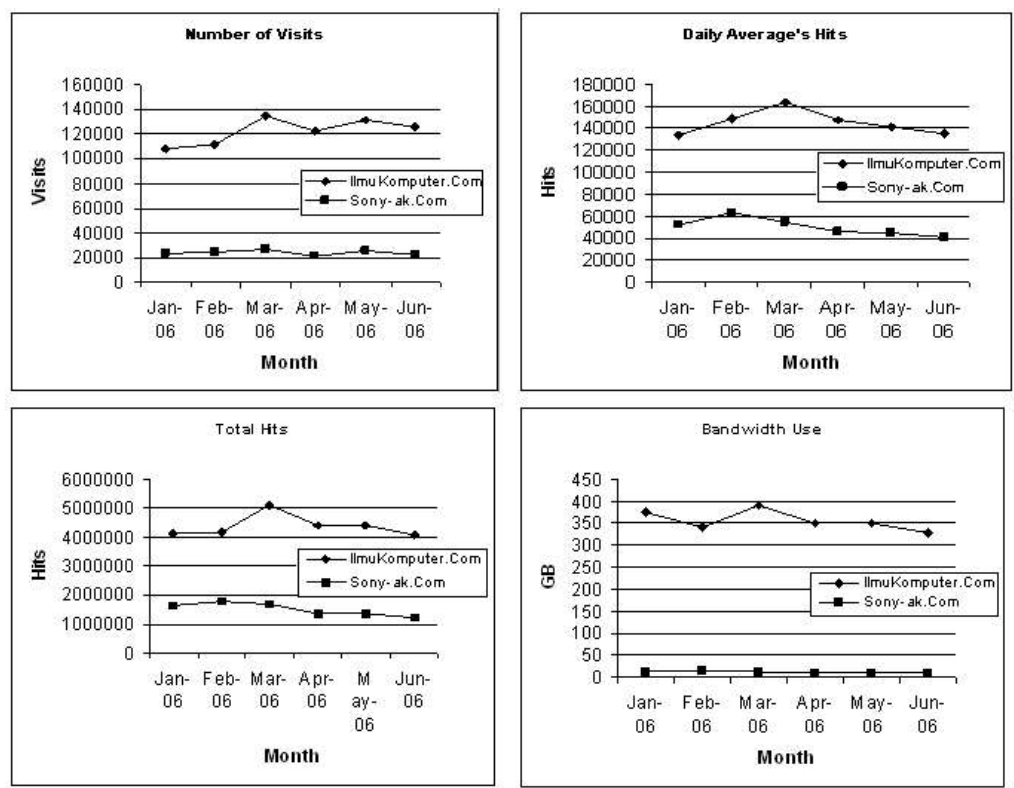

Gambar 5: Grafik Komparasi IImuKomputer.Com dan Sony-ak.Com

Kemudian menurut data dari Alexa.Com, Traffic Rank dari IImuKomputer.Com adalah 204.531, dan ini juga sangat jauh diatas Sony-ak.Com yang hanya menempati posisi 1.170.970 (Tabel 2). Demikian juga dari jumlah situs lain yang memasang taut, tercatat 74 situs untuk IlmuKomputer.Com, dan 12 situs untuk Sonyak.Com. Komparasi dengan sistem e-Learning lain (PakarKomputer.Com dan Benpinter.Com) juga dilakukan dengan pengujian data statistik yang ada di Alexa.Com, hasilnya seperti pada Tabel 2. 
Tabel 2: Komparasi Traffic Rank menurut Alexa.Com

\begin{tabular}{|l|l|l|l|l|}
\hline Penilaian & $\begin{array}{l}\text { Imukomputer. } \\
\text { Com }\end{array}$ & Sony-ak.Com & $\begin{array}{l}\text { PakarKomputer. } \\
\text { Com }\end{array}$ & Benpinter.Net \\
\hline Traffic Rank & 204.531 & 1.170 .970 & 2.371 .030 & 964.756 \\
\hline $\begin{array}{l}\text { Jumlah Situs } \\
\text { Yang } \\
\text { Memasang Taut }\end{array}$ & 74 & 12 & 0 & 7 \\
\hline
\end{tabular}

Dari hasil ini dapat dianalisa bahwa model motivasi komunitas secara umum sangat efektif berperan dalam menghasilkan suatu sistem e-Learning yang dikunjungi dan dijadikan referensi penting oleh banyak pengguna.

\section{- Hubungan Konsep AKSI dan DAMPAK}

Data statistik kunjungan IImuKomputer.Com bulan Januari 2006 menarik untuk dianalisa, karena menunjukkan ada hubungan antara Konsep AKSI (khususnya Subkonsep Kegiatan) dengan DAMPAK (khususnya Hits). Pada tanggal 19 Juni 2006, IlmuKomputer.Com menambah fitur layanan yaitu Radio Internet, dimana Radio ini mengudara untuk membahas tema-tema teknologi informasi yang sudah dijadwalkan [Wahono, 2006]. Ternyata kemudian terjadi tingkatan kunjungan yang sangat signifikan, dimana pada tanggal 19 Juni kunjungan (hits) mencapai 166705 dan mencapai tertinggi pada tanggal 20 Juni yang mencapai 184848 kunjungan (Gambar 6). Kondisi ini bertahan sampai tanggal 26 Juni 2006. Yang patut dicatat bahwa terjadi kenaikan yang cukup tinggi juga pada tanggal 24 Juni 2006 yang mencapai 181810, karena pada saat itu disampaikan undangan kepada seluruh komunitas untuk menjadi nara sumber di Radio Internet IlmuKomputer.Com [Sutiyadi, 2006].

Fenomena kenaikan kunjungan juga terjadi berhubungan dengan pengumuman kegiatan workshop gratis, update artikel baru, update ISO image, ataupun fitur-fitur baru yang ditambahkan di sistem eLearning. Tanggal 21-22 Juni (Sabtu-Minggu) tidak diperhitungkan, karena secara umum (2003-2006) tren kunjungan Sabtu dan 
Minggu selalu menurun dibandingkan dengan hari kerja. Hal ini memberi petunjuk bahwa kebanyakan penguna menggunakan hari kerja dan fasilitas publik, baik universitas atau kantor untuk mengakses IlmuKomputer.Com.

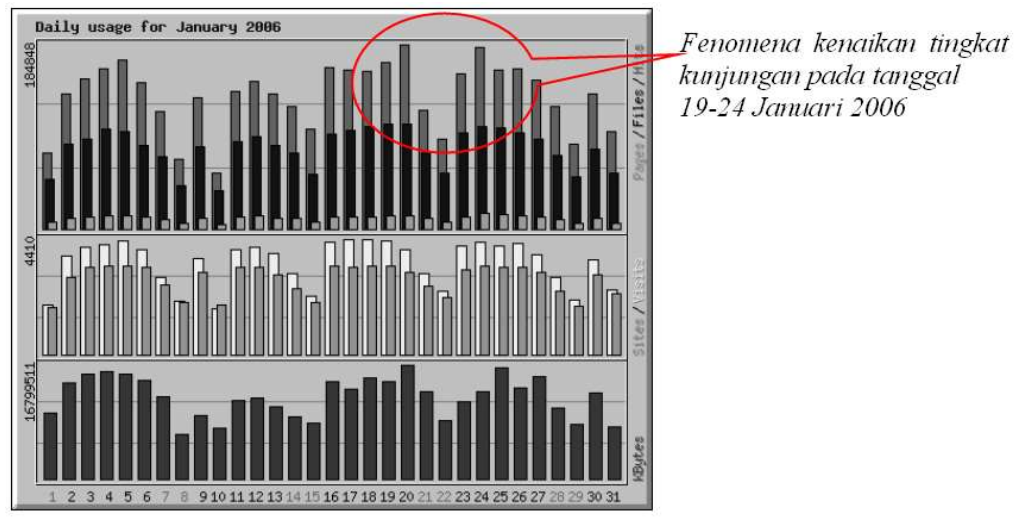

Gambar 6: Data Statistik Kunjungan Bulan Januari 2006

\section{- Hubungan Konsep PROMOSI dan DAMPAK}

Tabel 3 menunjukkan bahwa mesin pencari dalam Konsep PROMOSI sangat efektif dalam meningkatkan kunjungan. Terminologi Referrer pada Tabel 3 menunjukkan bahwa situs tersebut menjadi referensi (taut) awal dalam menemukan IImuKomputer.Com. Data menunjukkan bahwa mesin pencari google.co.id (google.com) menempati peringkat tinggi sebagai referrer dari IImuKomputer.Com, yaitu rangking referrer ke 2, 3 dan 5. Peringkat 4 adalah juga dari mesin pencari, yaitu yahoo.com. Tempat tertinggi tentu saja dari kunjungan langsung, dimana pengguna langsung mengetik URL IImuKomputer.Com pada web browser. Data diambil secara acak, yaitu Nopember 2005, Januari dan April 2006. 
Tabel 3: Tingkat Referrer IlmuKomputer.Com

\begin{tabular}{|l|l|}
\hline Bulan & 5 Besar Referrer \\
\hline Nopember 2005 & $\begin{array}{l}\text { 1. http://ilmukomputer.com } \\
\text { (kunjungan langsung) }\end{array}$ \\
& $\begin{array}{l}\text { 2. http://google.co.id/search } \\
\text { 3. http://google.com/search } \\
\text { 4. http://search.yahoo.com/search } \\
\text { 5. http://d-bests.com/index.php }\end{array}$ \\
\hline Januari 2006 & $\begin{array}{l}\text { 1. http://ilmukomputer.com } \\
\text { (kunjungan langsung) }\end{array}$ \\
& $\begin{array}{l}\text { 2. http://google.co.id/search } \\
\text { 3. http://google.com/search } \\
\text { 4. http://search.yahoo.com/search } \\
\text { 5. http://72.14.203.104/search } \\
\text { (google.com) }\end{array}$ \\
\hline April 2006 & $\begin{array}{l}\text { 1. http://www.ilmukomputer.com } \\
\text { (kunjungan langsung) }\end{array}$ \\
$\begin{array}{l}\text { 2. http://google.co.id/search } \\
\text { 3. http://google.com/search } \\
\text { 4. http://search.yahoo.com/search } \\
\text { 5. http://72.14.203.104/search } \\
\text { (google.com) }\end{array}$ \\
\hline
\end{tabular}

Selain itu, Konsep PROMOSI terutama berhubungan dengan Subkonsep Kerjasama, menimbulkan DAMPAK ekonomi. Lapangan kerja baru terbentuk, banyak proyek pengembangan eLearning bisa dikerjakan. Perusahaan-perusahaan besar (Merpati Airline, Microsoft), universitas (ITS Surabaya, Ubinus, UIN Syarif Hidayatullah), lembaga pemerintah (Departemen Pendidikan Nasional, Pemda Palangkaraya, Pemda Bogor) menjalin kerjasama bisnis dengan I/muKomputer.Com berhubungan dengan pengembangan eLearning. 


\section{- Hubungan Konsep DAMPAK dan MODAL}

Konsep DAMPAK terutama masalah ekonomi berpengaruh terhadap Konsep MODAL baik Internal maupun Eksternal. Dengan kekuatan ekonomi, IImuKomputer.Com mampu memiliki infrastruktur server sendiri yang sifatnya dedicated (sejak awal tahun 2004). Konsep DAMPAK juga membawa pengaruh ke MODAL terutama Subkonsep Jaringan, Partner, Teknologi, Sumber Daya Manusia, dsb. Partner dan Jaringan yang terbentuk diantaranya ada pada Tabel 4.

Tabel 4: Partner dan Jaringan IImuKomputer.Com

\begin{tabular}{|l|l|}
\hline Partner & Kegiatan \\
\hline Merpati Airline & $\begin{array}{l}\text { Pengembangan sistem eLearning untuk Merpati } \\
\text { Training Center }\end{array}$ \\
\hline ITS Surabaya & $\begin{array}{l}\text { Pengembangan sistem eLearning untuk } \\
\text { Fakultas Teknologi Informasi, ITS Surabaya }\end{array}$ \\
\hline Depdiknas & $\begin{array}{l}\text { Lomba media pembelajaran berbasis teknologi } \\
\text { informasi }\end{array}$ \\
\hline Microsoft & $\begin{array}{l}\text { Pengembangan sistem eLearning berbasis } \\
\text { ASP.Net dan workshop pemrograman }\end{array}$ \\
\hline UIN Syarif Hidayatullah & $\begin{array}{l}\text { Workshop eLearning dan multimedia } \\
\text { pembelajaran }\end{array}$ \\
\hline Universitas Indonesia & $\begin{array}{l}\text { Workshop eLearning dan lomba multimedia } \\
\text { pembelajaran }\end{array}$ \\
\hline Universitas Bina Nusantara & $\begin{array}{l}\text { Workshop eLearning dan multimedia } \\
\text { pembelajaran }\end{array}$ \\
\hline $\begin{array}{l}\text { Pemda Palangkaraya dan } \\
\text { Bogor }\end{array}$ & $\begin{array}{l}\text { Pengembangan Sistem Informasi dan } \\
\text { eLearning }\end{array}$ \\
\hline
\end{tabular}




\section{- Hubungan Konsep DAMPAK dan ORGANISASI}

Pada akhir Nopember 2003, IImuKomputer.Com mendapatkan penghargaan dari PBB dalam event WSIS di Jenewa. Data dibawah adalah data perubahan yang terjadi kurang lebih sampai 6 bulan setelah menerima penghargaan tersebut. Terjadi peningkatan yang signifikan setelah penghargaan diterima, khususnya untuk Jumlah Penulis, Pengurus, Forum Diskusi, Anggota Forum serta Rata-Rata Kunjungan Harian (Tabel 5). Penghargaan yang merupakan Subkonsep dari Konsep DAMPAK berpengaruh ke Konsep ORGANISASI.

Tabel 5: Kondisi Sebelum dan Setelah Menerima Penghargaan PBB (WSIS Desember 2003)

\begin{tabular}{|l|l|l|}
\hline & $\begin{array}{l}\text { Sebelum(April- } \\
\text { Nopember 2003) }\end{array}$ & $\begin{array}{l}\text { Setelah(Desember } \\
\text { 2003-Mei 2004) }\end{array}$ \\
\hline Jumlah Penulis & 54 & 138 \\
\hline Jumlah Pengurus & 7 & 18 \\
\hline $\begin{array}{l}\text { Jumlah Forum } \\
\text { Diskusi }\end{array}$ & 3 & 10 \\
\hline $\begin{array}{l}\text { Jumlah Anggota } \\
\text { Forum }\end{array}$ & 3000 & 20000 \\
\hline $\begin{array}{l}\text { Rata-Rata } \\
\text { Kunjungan Harian }\end{array}$ & 69150 & 90056 \\
\hline
\end{tabular}

- Hubungan Konsep DAMPAK, REQUIREMENT dan AKSI

Konsep DAMPAK ternyata berhubungan juga dengan Konsep REQUIREMENT. Kebutuhan baru muncul dari komunitas karena ada masalah berhubungan dengan penggunaan sistem e-Learning IImuKomputer.Com. Kebutuhan dan masalah ini nanti akan berhubungan dengan adanya penambahan fitur dan fungsi pada sistem e-Learning dan juga kegiatan baru dalam Konsep AKSI. Beberapa kebutuhan baru yang muncul sejak awal tahun 2004 (kurang lebih 1 tahun setelah launching), seperti pada Tabel 6. 
Tabel 6: Masalah dan Kebutuhan Baru

\begin{tabular}{|l|l|}
\hline \multirow{2}{*}{ Masalah } & Kebutuhan \\
\hline \multirow{2}{*}{ Akses internet terbatas } & $\begin{array}{l}\text { CDROM IImuKomputer.Com } \\
\text { (Offline) }\end{array}$ \\
\cline { 2 - 2 } & Mirror server di seluruh Indonesia \\
\hline $\begin{array}{l}\text { Penyebaran CDROM ke berbagai } \\
\text { daerah }\end{array}$ & Distributor CDROM di berbagai daerah \\
\hline Banyaknya artikel yang masuk & $\begin{array}{l}\text { Tim khusus untuk editing dan reviewing } \\
\text { tulisan }\end{array}$ \\
\hline $\begin{array}{l}\text { Pembelajaran lebih interaktif dan } \\
\text { tidak hanya dalam bentuk tulisan }\end{array}$ & Radio online \\
\cline { 2 - 2 } $\begin{array}{l}\text { Bimbingan belajar secara realtime } \\
\text { dengan pembimbing (konsultan) yang } \\
\text { ahli di bidangnya }\end{array}$ & Konsultasi online lewat Yahoo Messenger \\
\hline $\begin{array}{l}\text { Memerlukan ujian online dan } \\
\text { sertifikat resmi }\end{array}$ & Penambahan fitur yang memungkinkan \\
\hline
\end{tabular}

\section{KESIMPULAN DAN SARAN}

Di balik perkembangan konsep dan aplikasi eLearning, dewasa ini industri e-Learning sedang mengalami krisis, yang berakibat ke kegagalan penerapan e-Learning di berbagai sektor di dunia. Kegagalan terutama disebabkan karena pengguna yang sangat sedikit dan tidak termotivasi untuk menyelesaikan materi e-Learning sampai akhir. Makalah ini memberikan solusi dengan mengembangkan sistem e-Learning berbasis model motivasi komunitas yang dapat mengatasi rendahnya pengguna dan tidak termotivasinya pengguna dalam menggunakan sistem eLearning.

Model telah diterapkan pada sistem e-Learning publik IImuKomputer.Com. Indikator pengukuran efektifitas model menggunakan data statistik kunjungan, traffic ranking, komparasi dengan sistem e-Learning sejenis, dan hubungan antar konsep dalam model. Dari hasil pengukuran dengan beberapa indikator tersebut, dapat disimpulkan bahwa model motivasi komunitas cukup efektif digunakan untuk pengembangan dan penerapan sistem eLearning, 
khususnya untuk sistem e-Learning publik berbasis web.

Setelah penerapan di sistem e-Learning publik berjalan dengan baik, saat ini sistem e-Learning dengan strategi implementasi berbasis ke model motivasi komunitas dalam waktu dekat akan diterapkan di pendidikan formal di Indonesia (Fakultas Teknik Informatika Institut Teknologi Sepuluh Nopember (ITS) Surabaya), perusahaan penerbangan (Merpati Airline), serta di dunia perbankan yaitu Bank ABN Amro dan Bank BNI. Diharapkan model akan semakin matang dengan adanya studi kasus penerapan sistem e-Learning di berbagai bidang tersebut.

\section{DAFTAR PUSTAKA}

Delio, M., 2000. Report: Online Training 'Boring', Wired Magazine, Wired Digital Inc., August 30.

Dublin, L., \& Cross J., 2003. Implementing eLearning: Getting the Most from Your e-Learning Investment, The ASTD International Conference, May.

Gamma E., Helm R., Johnson R., \& Vlissides J., 1995. Design Patterns:

Elements of Reusable Object-Oriented Software, Addison-Wesley Professional Computing Series.

Hall, J., Healy, K.A., \& Ross, R.G., 2005. The Business Motivation Model Business Governance in a Volatile World, The Business Rules Group (BusinessRulesGroup.org), September.

Hannay, M., \& Newvine, T., 2006. Perceptions of Distance Learning: A Comparison of Online and Traditional Learning, MERLOT Journal of Online Learning and Teaching, Vol. 2 No. 1 March.

Hartley, D.E., 2001. Selling e-Learning, American Society for Training and Development.

IEEE Std 610.12., 1990. IEEE Standard Glossary of Software Engineering Technology, IEEE Std 610.12-1990, Institute of Electrical and Electronics Engineers, New York.

Jo Kim, A., 2000. Community Building on the Web: Secret Strategies for Successful Online Communities, Peachpit Press, Berkeley. 
Leffingwell, D., \& Widrig, D., 2000. Managing Software Requirements - A Unified Approach, Addison Wesley.

Martens, R.L., Gulikersw J., Bastiaensw T., 2004. The Impact of Intrinsic Motivation on e-learning in Authentic Computer Tasks, Journal of Computer Assisted Learning, 20, pp368-376, Blackwell Publishing. Morgan, C.T., 1961. Introduction to Psychology, USA: McGraw-Hill. Onggo, B.J., 2005. Cyber Branding through Cyber Marketing, Elex Media Komputindo.

Wahono, R.S., \& Cheng J., 2002. Extensible Requirements Patterns of Web Application, IEEE International Symposium on Cyber Worlds (CW 2002), Japan.

Wahono, R.S., 2003. Analyzing Requirements Engineering Problems, IECI Japan Workshop 2003 (IJW-2003), Japan.

Wahono, R.S., 2004. Strategi Mengelola e-Learning Gratis Berbasis Komunitas, Majalah Bisnis Komputer, No. 9, Oktober.

Wahono, R.S., 2005 Menghidupkan Pengetahuan Sudahkah Kita Lakukan?, Jurnal Dokumentasi dan Informasi - Baca, Lembaga IImu Pengetahuan Indonesia, Desember.

Wahono, R.S., 2006. Radio Online IImuKomputer.Com, Arsip Mailing List No \#39352, ilmukomputer@yahoogroups.com, 19 Juni.

Sutiyadi, M., 2006. Tawaran Menjadi Pembicara/Nara Sumber di Radio Online IImuKomputer.Com, Arsip Mailing List No \#39447, ilmukomputer@yahoogroups.com, 24 Juni.

U.S. Department of Commerce, 2002. 2020 Visions: Transforming Education and Training Through Advanced Technologies, The Use of Advanced Technologies in Education and Training Summit, U.S. Department of Commerce.

Vliet, H.V., 2000. Software Engineering - Principles and Practice, John Wiley \& Sons.

- Email: romi@romisatriawahono.net

- URL: http://romisatriawahono.net 